\title{
Culicidae (Diptera) selection of humans, chickens and rabbits in three different environments in the province of Chaco, Argentina
}

\author{
Marina Stein ${ }^{1 /+}$, Laura Zalazar², Juana Alicia Willener ${ }^{1}$, \\ Francisco Ludueña Almeida ${ }^{3}$, Walter Ricardo Almirón ${ }^{3}$

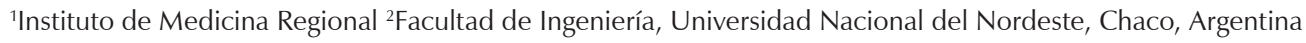 \\ ${ }^{3}$ Centro de Investigaciones Entomológicas, Universidad Nacional de Córdoba, Córdoba, Argentina
}

\begin{abstract}
Studies were conducted to determine the selection of humans, chickens and rabbits by Culicidae in three different environments in the province of Chaco, Argentina. Mosquitoes were collected fortnightly using cylindrical metal traps containing animal bait (chickens and rabbits). The mosquitoes were collected between June 2001-May 2002. During the same period and with the same frequency, mosquitoes biting the human operators of the traps were collected during the first 15 min of exposure within different time intervals: from 09:00 am-11:00 am, 01:00 pm-03:00 pm, 05:00 pm-07:00 pm and 09:00 pm-10:00 pm. A total of 19,430 mosquitoes of 49 species belonging to 10 genera were collected. Culex species mainly selected chicken bait and Wyeomyia species selected rabbit bait. Ochlerotatus and Psorophora species were more abundant in rabbit-baited traps. Anopheles triannulatus, Coquillettidia nigricans, Ochlerotatus scapularis, Mansonia titillans and Psorophora albigenu showed a strong attraction for human bait. The Anopheles, Coquillettidia, Culex and Mansonia species were more active between 05:00 pm-09:00 pm, while Ochlerotatus, Psorophora, Haemagogus and Wyeomyia were most active from 09:00 am-07:00 pm. This study provides additional information about the biology and ecology of arbovirus vectors in Chaco.
\end{abstract}

Key words: host selection - Culicidae - Chaco - Argentina

The degree of association between vectors and their hosts is an important indicator of the intensity of disease transmission (Dye 1992). Knowledge of host preferences provides important insight into the dynamics of virus transmission and could aid in the design and implementation of efficient strategies for vector control. Nevertheless, few studies addressing the host selection of mosquitoes have been conducted in Argentina. Hack et al. (1978) documented that mosquitoes were attracted to humans and Almirón and Brewer (1995) examined the roles of chickens, rabbits and turtles as hosts. A variety of hosts (humans, horses, hamsters and chickens) were tested for host selection by Mitchell et al. $(1985,1987)$. Recent studies examining human sera in the provinces of Chaco and Corrientes revealed high rates of infection with flaviviruses (26\%). Human antibodies against St. Louis encephalitis virus (SLEV) and West Nile virus (WNV) were also detected and there was a seroprevalence of $13 \%$ for alphaviruses, with the Pixuna and Rio Negro viruses being responsible for these infections (Beskow et al. 2007). Pisano et al. (2007) isolated the Pixuna and Rio Negro viruses from mosquitoes captured in Monte Alto and Resistencia (Chaco) between December 2003April 2004. The mosquitoes examined by these authors belonged to the Culex, Ochlerotatus and Psorophora genera. Diaz et al. (2008) detected WNVs in birds (8/82)

doi: 10.1590/0074-0276108052013005

Financial support: Secretaría General de Ciencia y Técnica UNNE (PI-538)

+ Corresponding author: marinastein@yahoo.com.ar

Received 15 October 2012

Accepted 2 January 2013 captured at Monte Alto during 2004 and 2005. Our data detail the selection of different hosts by Culicidae as well as their seasonal variations and time of activity in this region, expanding our knowledge of vector biology and the arbovirus transmission cycle in Chaco.

\section{MATERIALS AND METHODS}

The study site and the surrounding area were described by Stein et al. (2011) (Fig. 1). Mosquitoes were captured fortnightly using human and animal bait between June 2001-May 2002. Four cylindrical metal traps, each containing a single chicken or rabbit (average weight $=1.5 \mathrm{~kg})$, were used ( 2 with chickens and 2 with rabbits) (Service 1993). The traps were put in place at the same time (12 total traps) in three types of environments (sites): urban (Resistencia) $\left(27^{\circ} 30^{\prime} \mathrm{S} 59^{\circ} \mathrm{W}\right)$, semi-urban (Monte Alto) $\left(27^{\circ} 26^{\prime} 38^{\prime \prime} \mathrm{S} 58^{\circ} 55^{\prime} 3^{\prime \prime} \mathrm{W}\right)$ and wild (Kilometer 1,031$)\left(27^{\circ} 10^{\prime} \mathrm{S} 58^{\circ} 58^{\prime} \mathrm{W}\right)$. The chickens and rabbits were immobilised and enclosed in wire and metal mesh, respectively, to avoid mosquitoes being eaten or killed by the bait animals. Each of the traps always contained the same type of baits. The cylindrical metal traps were separated by a distance of greater than $50 \mathrm{~m}$ and set at a height of $1.5 \mathrm{~m}$ above the ground. They remained active between 06:00 pm-08:00 am during each capture. The trapped mosquitoes were aspirated mechanically using battery operated aspirators (Service 1993). Additionally, two operators at the semi-urban site used battery aspirators to capture mosquitoes during the first $15 \mathrm{~min}$ of exposure within the following time intervals: from 09:00 am-11:00 am, 01:00 pm-03:00 pm, 05:00 pm-07:00 $\mathrm{pm}$ and 09:00 pm-10:00 pm. The specimens captured on both the animal and human bait were stored in labelled glass bottles lined with porous paper. 
Processing of the specimens in the laboratory - The collected specimens were asphyxiated with ethyl acetate, identified and counted. Specimen identification was based on examination of adults following the characteristics outlined in Lane (1953), Forattini (1962, 1965a, b), Ronderos and Bachmann (1962), Bram (1967), Darsie (1985) and Consoli and Lourenço-de-Oliveira (1994). The specimens were deposited into the entomological collections of the Regional Institute of Medicine, National University of the Northeast (Chaco) and the Entomology Research Center, Building for Biological Research and Technology, Faculty of Exact, Physical and Natural Sciences, National University of Córdoba (Córdoba).

Data analysis - A Pearson's chi-square test was used to compare the differences in the relative abundance of species between mosquitoes collected on chicken and rabbit bait and between mosquitoes collected on animal and human bait. Contingency tables were also generated to test the differences between blood-fed and unfed females collected on the same bait. The type of bait (rows) was used as a classification variable (chicken or rabbit) and the response variable was blood-fed vs. unfed females (columns). The odds ratio (OR) was estimated for each species to quantify the association between the two variables (bait and feeding). Pearson's chi-square was also applied to compare the relative abundance of the mosquito species captured in different habitats on animal bait and the activity intervals on human bait. The obtained data were analysed with the statistical software program InfoStat (Di Rienzo et al. 2011). William's mean was used as a measure of the central tendency to calculate the monthly average values of the mosquito species on different bait types.

\section{RESULTS}

Animal bait - A total of 14,044 specimens were captured on the animal bait $(60.45 \%$ on rabbits and $39.55 \%$ on chickens) in the present study. A total of 45 species ( 42 on rabbits and 36 on chickens) belonging to eight genera were identified. Aedeomyia squamipennis (Lynch Arrib-

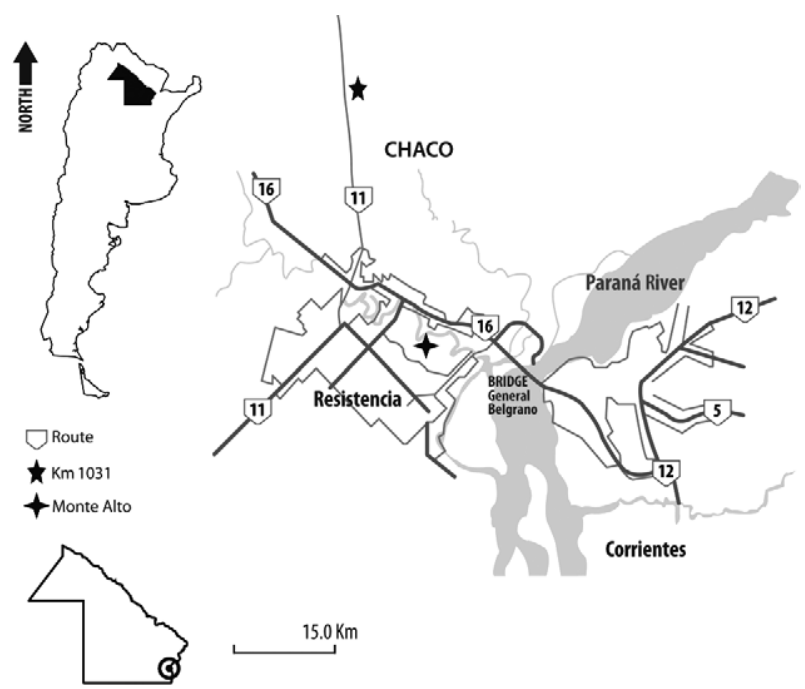

Fig. 1: map of the study area. Modified from Stein et al. (2005). alzaga) $(0.16 \%)$, Anopheles albitarsis Lynch Arribalzaga $(0.02 \%)$, Coquillettidia albicosta (Peryassu) $(0.02 \%)$ and Mansonia flaveola Coquillett (0.02\%) were caught only with chicken bait. Coquillettidia shannoni Lane \& Antunes (0.01\%), Culex saltanensis Dyar (0.08\%), Mansonia pseudotitillans Theobald (0.01\%), Ochlerotatus albifasciatus Macquart (0.01\%), Ochlerotatus crinifer Theobald (0.01\%), Psorophora cingulata Fabricius (0.05\%), Psorophora confinnis Arribalzaga (0.13\%), Psorophora pallescens Edwards (0.05\%) and Psorophora varinervis Edwards $(0.05 \%)$ were captured only with rabbit bait. The genus Culex contributed $87.25 \%$ of the specimens captured on chickens and $59.74 \%$ of those captured on rabbits. Twenty-two species showed significant differences between the females captured using chicken vs. rabbit bait $(\mathrm{p}<0.001)$ (Supplementary data). Only Culex quinquefasciatus Say and Culex chidesteri Dyar were significantly more abundant in the chicken-baited traps $\left(x^{2}=1,204.43\right.$, $\mathrm{p}<0.0001 ; x^{2}=13.55, \mathrm{p}<0.001$ respectively).

Blood-fed mosquitoes captured on animal bait - No analyses of the blood contents of captured mosquitoes were performed. Nevertheless, mosquitoes containing red blood (freshly engorged) in their abdomen were considered to have fed on the animal bait because once they were in the trap they could not escape. Following this criterion, $85.31 \%$ of the specimens collected using chicken bait were found to be blood-fed, but only $66.95 \%$ of those captured on rabbit bait were blood-fed. The proportion of fed females in relation to the total number of females captured is shown in Fig. 2. Eight species exhibited significant differences between the number of blood-fed and unfed specimens on both types of animal bait (Fig. 2). For this analysis, we considered only species with a sample size of more than 10 females found on each type of bait. Culex bidens Dyar was cap-

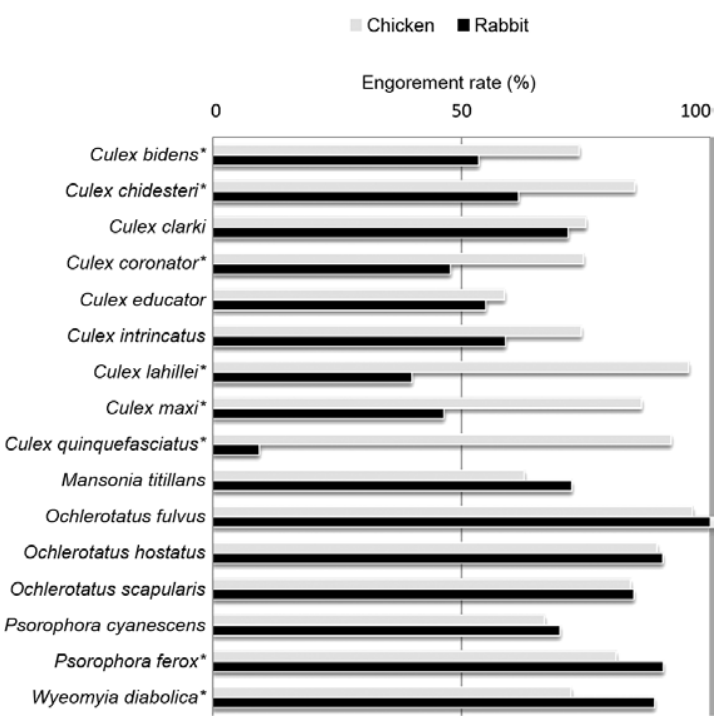

Fig. 2: percentages of mosquitoes (by species) in traps that engorged on chicken and rabbit bait in the province of Chaco, Argentina. Data are presented only when sample size was $>10$ females on each bait. Asterisk means $\mathrm{p}<0.001$. 
tured mostly on rabbit bait, but presented an OR $1 / 2(1=$ chicken, $2=$ rabbit) equal to $2.43[\mathrm{p}<0.001$; confidence interval $(\mathrm{CI})=95 \%$, indicating that it was more likely to feed on chicken bait. Conversely, Culex coronator Dyar \& Knab, Culex lahillei Bachmann and Casal and Culex maxi Dyar did not show statistically significant differences in their rates of capture on the different types of animal bait, but they were more likely to feed on chicken bait [OR $(1 / 2)=3.2,33$ and 7.2, respectively, $\mathrm{p}<0.0001]$. $C x$. chidesteri and $C x$. quinquefasciatus were more likely to feed on chicken bait (OR $(1 / 2)=3.5$ and 75.3, respectively, $\mathrm{p}<0.0001]$. Only Psorophora ferox (Von Humbolt) and Wyeomyia diabolica Lane and Forattini showed a greater likelihood of feeding on rabbit bait [OR $(2 / 1)=2.24$ and 3.7, respectively, $\mathrm{p}<0.05]$.

Environments - baits - At urban sites, Cx. bidens and $C x$. maxi were captured in higher proportions using chicken bait, whereas at semi-urban and wild sites they were more often captured in rabbit-baited traps $\left(x^{2}=128.79\right.$ and $x^{2}=163.56$, respectively, $\mathrm{p}<0.0001$ ) (Fig. 3). No significant differences or associations between the environments and bait types were found for the other species.

Seasonal distribution analysis and host selection No collections were conducted in January. In November and February, collections were only performed in the urban environment. Consequently, only data on the most frequent species obtained in the collections conducted from March-December are shown (Fig. 4). Cx. bidens, Cx. chidesteri, Cx. maxi, Cx. quinquefasciatus, Mansonia titillans Walker, Ochlerotatus scapularis Rondani and Ps. ferox showed similar behaviours in all months in which collections were performed on both bait species (Fig. 4). Wy. diabolica and Wyeomyia muelhensi fed on both bait species equally from June-October, but fed only on the rabbit bait from March-May (Fig. 4). In contrast, Ochlerotatus fulvus (Wiedemann) and Ochlerotatus stigmaticus Edwards fed only on the rabbit bait between July-October and fed on both types of bait between March-May (Fig. 4).

Human bait - A total of 5,386 specimens were captured on human bait, belonging to nine genera and 42 species (Supplementary data). A high percentage (82\%) of species was captured on both human and animal bait. Eleven species contributed $89.95 \%$ of the total specimens captured. These species are, in descending order, $O c$. scapularis (46.07\%), Ma. titillans $(10.60 \%)$, Anopheles triannulatus Neiva and Pinto (8.80\%), Ps. ferox (5.80\%), Psorophora albigenu Peryassu (5.02\%), Ochlerotatus hastatus $(2.50 \%)$, Mansonia humeralis Dyar \& Knab (2.43\%), Cx. bidens (2.09\%), Oc. albifasciatus (1.75\%), An. albitarsis Arribalzaga (1.19\%) and Psorophora ciliata Fabricius (1.01\%). The remaining species were captured at rates of less than $1 \%$ (Supplementary data). Anopheles galvaoi Causey (0.07\%), Anopheles neomaculipalpus Curry (0.36\%), Haemagogus spegazzini Brethes (0.05\%), Psorophora albipes Theobald $(0.04 \%)$, Uranotaenia nataliae Arribalzaga $(0.02 \%)$ and Wyeomyia melanocephala Dyar \& Knab $(0.13 \%)$ were captured only on human bait. Anopheles species, Coquillettidia nigricans, Oc. scapularis, Ma. humeralis, Ma. titillans and Ps. albigenu showed a strong preference for human bait $(\mathrm{p}<0.0001)$ (Supplementary data).

Timing of activity - The time interval showing the greatest abundance of mosquitoes was 05:00 pm-07:00 pm $\left(x^{2}=773.78, \mathrm{p}<0.0001\right)$ (Fig. 5). Most Ochlerotatus and Psorophora species were more abundant during
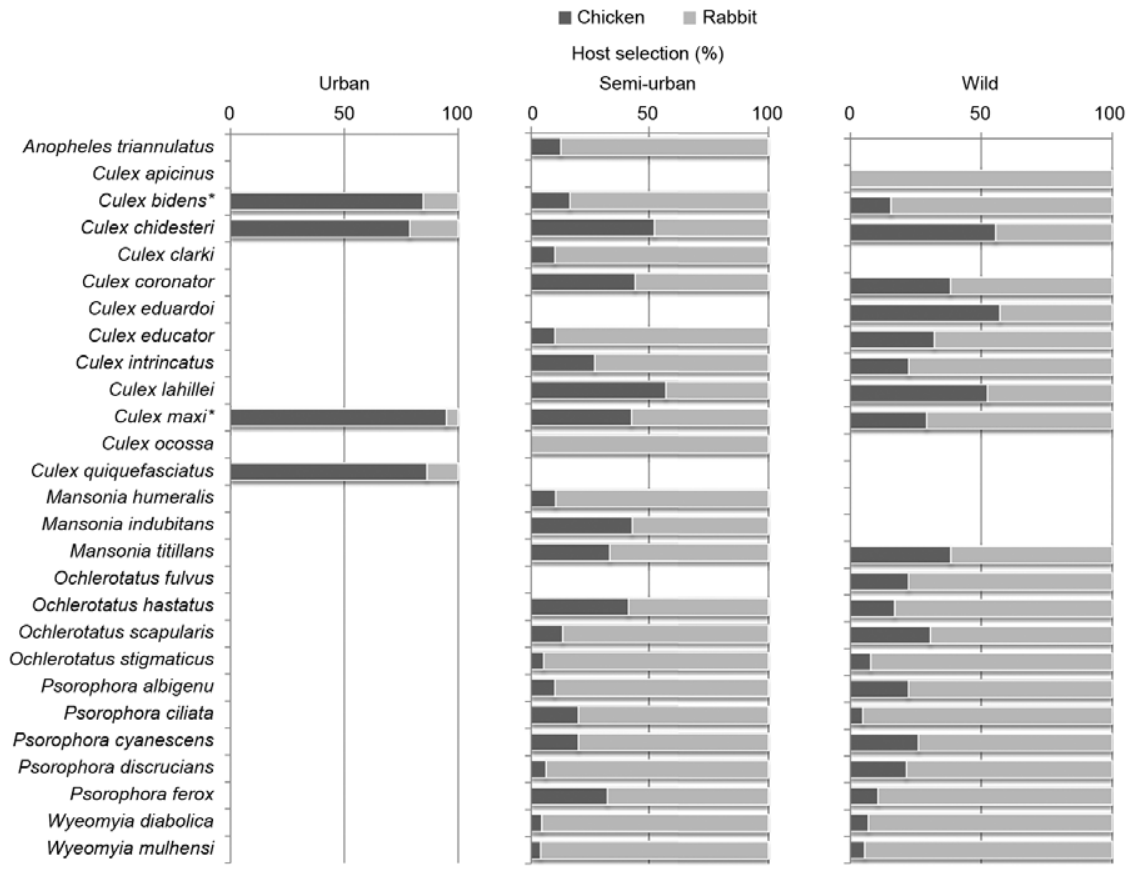

Fig. 3: mosquitoes captured on chicken and rabbit bait at urban, semi-urban and wild sites in province of Chaco, Argentina. Data are presented only when sample size was $>10$ females at a site. Asterisk means $\mathrm{p}<0.001$. 
the day and declined abruptly or became almost absent after 09:00 pm (Fig. 5). Most Anopheles, Coquilletidia, Culex and Mansonia species were more abundant during the evening and night intervals (Fig. 5). Wyeomyia species were captured until 05:00 pm and $H g$. spegazzini until 03:00 pm. An. triannulatus, Cx. bidens, Ma. titillans, Oc. albifasciatus, Oc. scapularis and Ps. albigenu were captured in all of the investigated time intervals (09:00 am-10:00 pm), though there were intervals showing higher activity of these species (Fig. 5).

Seasonal variations on human bait - The greatest abundance and variety of mosquito species captured on human bait were recorded in June, October, November and April (Fig. 6). Oc. scapularis and Ma. titillans were the only species captured during all sampling months. An. triannulatus and $C x$. bidens were more abundant between June-August (winter). Species of Ochlerotatus and Psorophora were mainly caught between October-December (spring) and between March-May (autumn), with the exception of Oc. albifasciatus, which was more abundant in the winter (Fig. 6). Half of the species were only captured in one, two or three months during the study. An. galvaoi, Cq. albicosta, Coquilletidia shanonni, Coquilletidia clarki, Culex eduardoi, Culex mollis, Ps. albipes,

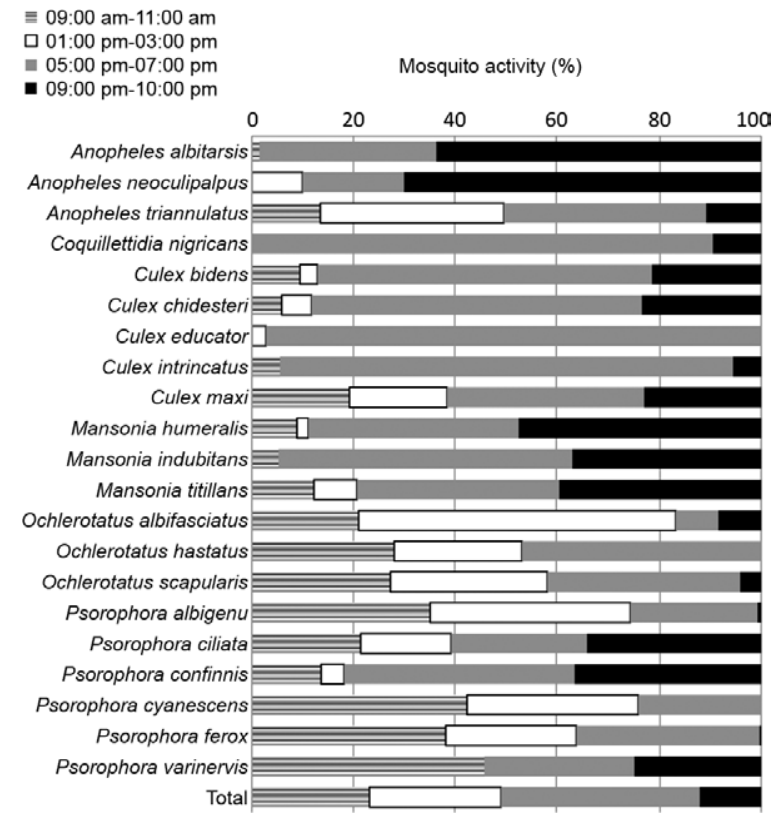

Fig. 5: mosquitoes species captured on human bait at different interval time in semi-urban environment in province of Chaco, Argentina. Data are presented only when sample size was $>10$ females.
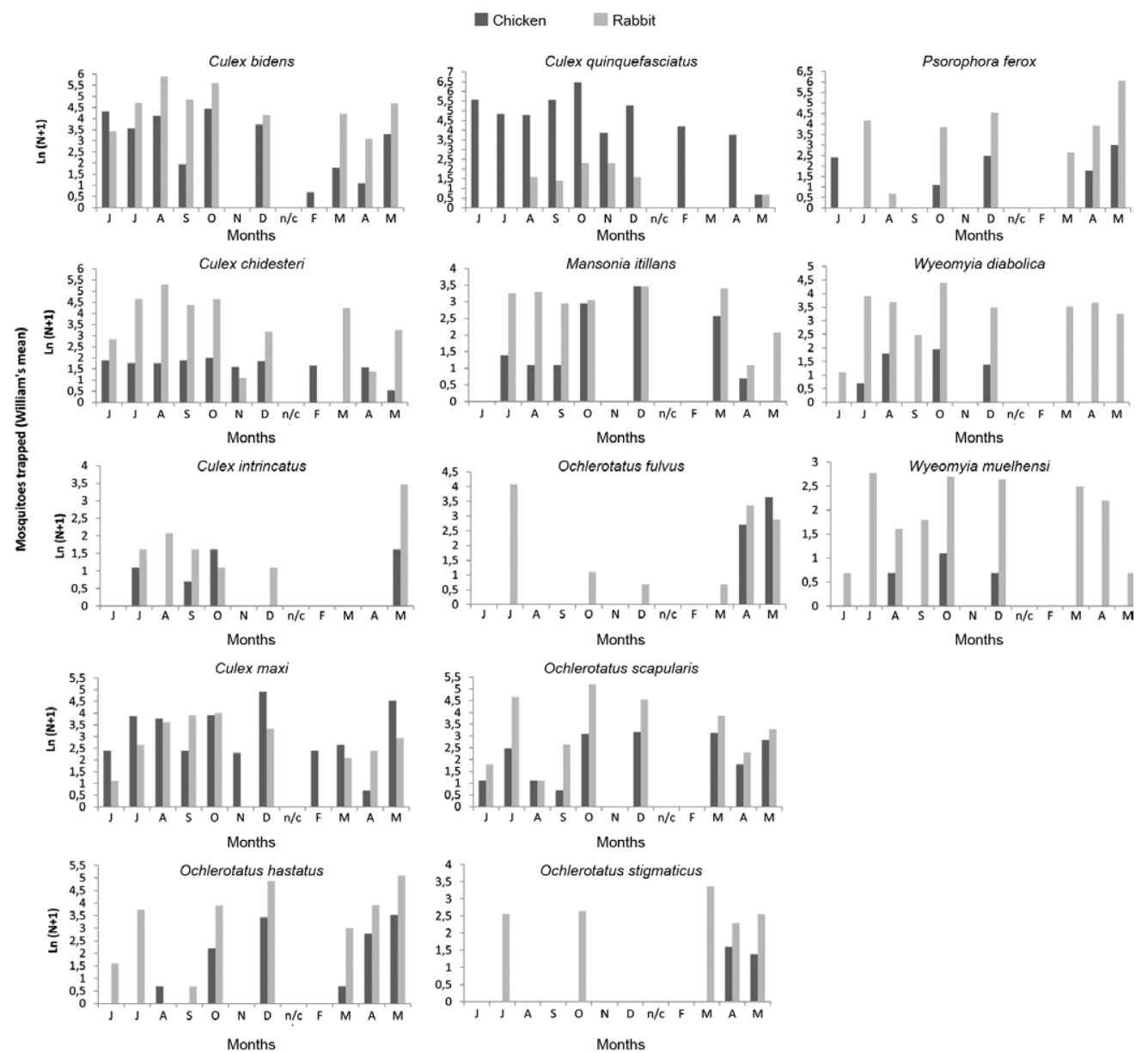

Fig. 4: number of mosquitoes captured on chicken and rabbit bait between June 2001-2002 in province of Chaco, Argentina. Data are presented only for the most abundant species. Ln: natural log; n: number of mosquitoes; n/c: no capture was done. 
Ps. cingulata and Ur. nataliae were caught in only one month. An. neomaculipalpus, Cx. lahillei, Culex ocossa, Hg. spegazzini, Ma. pseudotitillans, Oc. fulvus, Ochlerotatus serratus, Oc. stigmaticus, Ps. confinnis, Psorophora discruscians, Ps. varinervis, Wy. diabolica and Wy. melanocephala were collected in two or three months.

\section{DISCUSSION}

The results presented here are in agreement with studies that have concluded that Culex species show selection for birds, while the Ochlerotatus, Psorophora and Wyeomyia genera show a preference for mammals (Tempelis et al. 1967, Mitchell et al. 1985, Lourenço-de-Oliveira \& Heyden 1986, Lourenço-de-Oliveira et al. 1986, Forattini et al. 1987, Almirón \& Brewer 1995). These studies also mention the preference of Coquillettidia and Mansonia species for mammals. Our results show a clear selection of $C x$. quinquefasciatus and $C x$. chidesteri for chicken. Cx. bidens, Cx. coronator, Cx. lahillei and $C x$. maxi were attracted by both animal hosts, but they are more likely to feed on chicken bait. The chances of feeding on one of the types of animal bait did not differ significantly for the other species belonging to the Culex, Mansonia, Ochlerotatus and Psorophora genera, which were attracted by both bait species. Bait poor selectivity was also observed for the most Culex specimens from the Melanoconium subgenus. We believe that these species feed on both types of bait, in agreement with their designation as euritrophic mosquitoes (Natal 1981). Fo- rattini et al. (1987) found that Culex (Melanoconion) species fed on both birds and mammals.

In studies using different types of bait, Lourenço-deOliveira and Heyden (1986) captured Cx. bidens mainly on humans, but classified this species as showing a tendency to bite birds. Other hosts recorded were cows and horses for $C x$. chidesteri and Cx. bidens, respectively (Edman \& Downe 1964, Lourenço-de-Oliveira 1984, Lourenço-deOliveira \& Heyden 1986, Forattini et al. 1987).

Cx. quinquefasciatus is known for its high anthropophily (Charlwood 1979) and its ability to adapt to the anthropic environment (Almirón \& Brewer 1996, Oria et al. 2002, Stein et al. 2002). In the present study, as in the reports of other authors, Cx. quinquefasciatus stands out due to its ornithophily (Prosen et al. 1960, Forattini 1965a, Lourenço-de-Oliveira \& Heyden 1986, Forattini et al. 1987, Klein et al. 1992, Almirón \& Brewer 1995, Burkett-Cadena et al. 2008, Garcia-Rejon et al. 2010) and it is possible that this species was not captured on human bait because sampling was only conducted on humans in the semi-urban environment, where $C x$. quinquefasciatus was not found. In contrast with our findings, Almirón and Brewer (1995) captured a high percentage of $C x$. quinquefasciatus feeding on rabbits.

Ae. squamipennis and Ma. flaveola were only captured on chickens, in agreement with the findings of other authors (Gabaldon et al. 1977, Mitchell et al. 1985, Forattini et al. 1987, Teodoro et al. 1994, Tissot \& Navarro-Silva 2004). Ma. titillans and Oc. scapularis are the species that
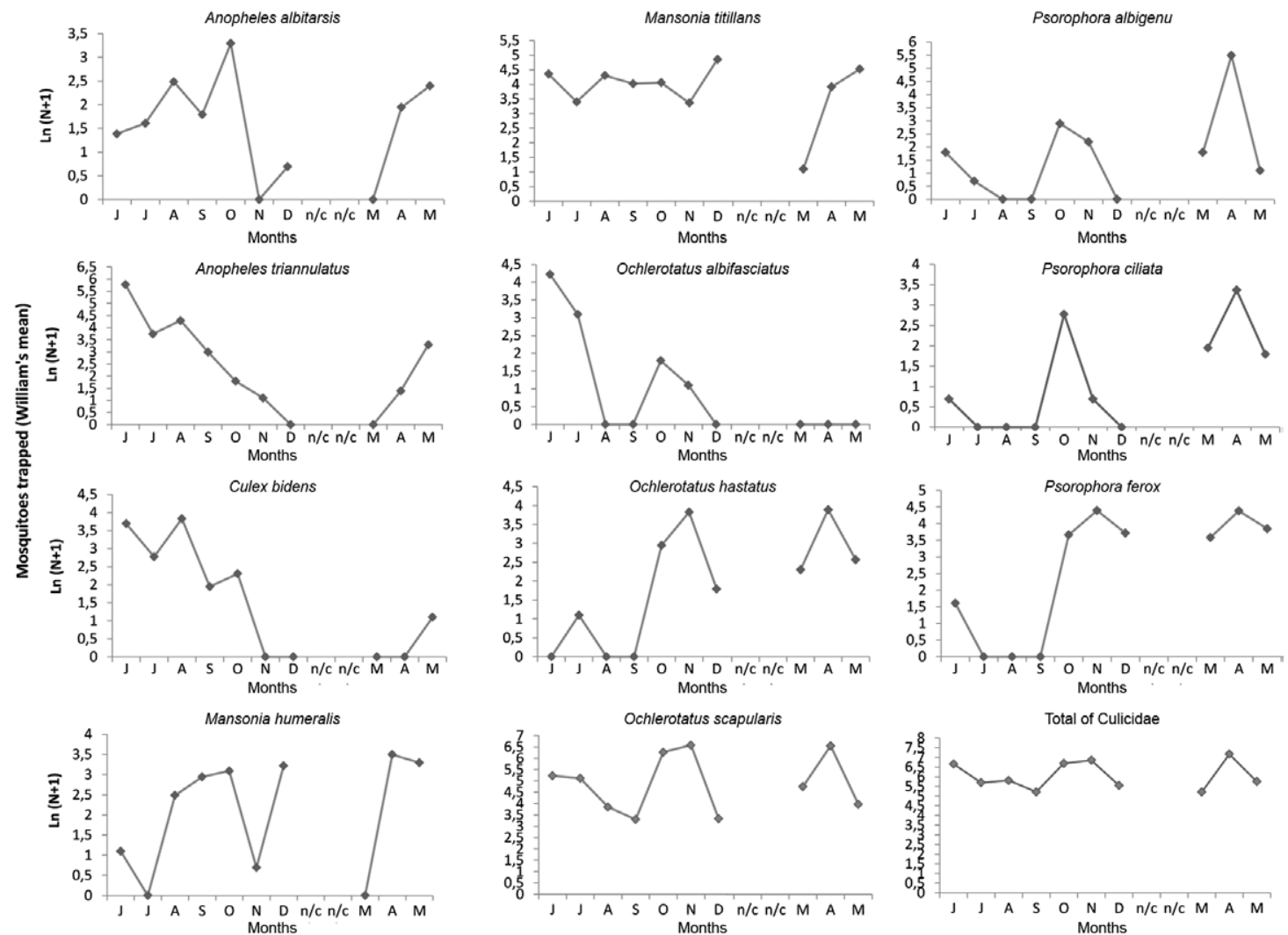

Fig. 6: number of mosquitoes captured on human bait between June 2001-May 2002 in province of Chaco, Argentina. Data are presented only for species with captures higher than $1 \%$. Ln: natural log; n: number of mosquitoes; $n / c$ : no capture was done. 
have presented the highest capture frequencies on human bait in other studies (Hack et al. 1978, Lourenço-de-Oliveira 1984, Lourenço-de-Oliveira \& da Silva 1985, Lourenço-de-Oliveira \& Heyden 1986). Ma. titillans can be attracted by different types of bait, including poikilothermic animals, but it appears to show a preference for large mammals, such as horses and cows (Lourenço-de-Oliveira \& Heyden 1986). Inside houses in rural areas of Brazil, this species is more abundant than $C x$. quinquefasciatus and comparative studies have shown that it is attracted to humans (Lourenço-de-Oliveira \& Heyden 1986).

Oc. scapularis has been identified as a species that is adapting to the anthropic environment (Forattini et al. 1987, 1995). Forattini et al. (1987) found a high percentage of human blood in Oc. scapularis specimens captured in households of São Paulo, Brazil. Other notable hosts of this species are horses and cows (Lourenço-deOliveira \& Heyden 1986). Mitchell et al. (1985) identified the blood of birds, marsupials, horses, Felidae, Canidae, Bovidae, Cervidae and Hominidae in Oc. scapularis specimens, indicating the broad host preference of this species. In this study, Oc. scapularis was more attracted to humans than to rabbits or chickens.

Our results regarding Oc. albifasciatus showed differences and similarities compared with other studies. In the present study, this species showed almost exclusive selection for humans, in agreement with Prosen et al. (1960) and Hack et al. (1978). In contrast, Mitchell et al. (1985) used horse, chicken and human bait and obtained the highest percentage of specimens from horses and only a single specimen from human bait in the province of Santa Fé. In Córdoba, Almirón and Brewer (1995) obtained high capture percentages of Oc. albifasciatus on chickens and rabbits and showed that this species preferentially feeds on chickens. We did not find any explanation for the different behaviours of Oc. albifasciatus in different climatic regions of Argentina, but we can conclude that it utilises a variety of hosts. Bidlingmayer (1985) demonstrated that each environment has specific characteristics that make it unique when considering the physiological needs of each mosquito species.

An. triannulatus is considered to be essentially zoophilic, although it may bite humans indoors (Lourenço-deOliveira \& Luz 1996, Brochero et al. 2006). In the present study, human bait attracted significantly more Anopheles species than animal bait. Gabaldon et al. (1977) captured high percentages of An. albitarsis on birds and Lourençode-Oliveira and Heyden (1986) captured this species on horses and cows in higher percentages than on humans. Analyses of mosquitoes collected in Chaco, Corrientes and Santa Fé by Mitchell et al. (1985) identified Bovidae blood in An. albitarsis and An. triannulatus.

Many environmental factors may act in combination with the innate preferences of a mosquito species to affect its final selection of a host. Moreover, the absence of a host or an increase in the mosquito population may favour those mosquitoes with an innate preference for a variety of hosts or could induce phenotypic plasticity to modify host selection patterns, without changing innate preferences (Tempelis et al. 1967, Lefèvre et al. 2009).
In the United States of America (USA), Culex pipiens undergoes a shift in its host preference from birds to humans at the end of summer. This change coincides with the migration of its preferred host (the American robin) (Kilpatrick et al. 2006). Almirón and Brewer (1995) concluded that $C x$. bidens and $C x$. quinquefasciatus feed mainly on rabbits in the summer and on chickens during both the spring and summer. In the same study, Oc. albifasciatus was more often captured on rabbits in the summer and on chickens in the autumn and spring; however, the authors did not offer any explanation for these observations (Almirón \& Brewer 1995). In the present study, Oc. fulvus and Oc. stigmaticus were mostly caught on rabbit bait, but when there was an explosion of both species in the autumn (March-May), the percentages of females on chickens increased considerably. In Venezuela, Berti et al. (2011) captured Oc. fulvus on human bait.

Ps. ferox showed strong selection for rabbit bait and, in agreement with other studies, was also very abundant on human bait (Gomes et al. 1987, da Silva \& Lozovei 1998). Wyeomyia species were observed to be markedly zoophilic and mainly selected rabbit bait. However, $W y$. melanocephala was captured only on human bait and this species has been observed biting humans in Brazil (Forattini 1965b).

Forattini et al. (1987) observed three specimens of Uranotaenia lowii on birds, amphibians and humans. Lourenço-de-Oliveira et al. (1985) found Ur. lowii to be the most abundant species captured in CDC light traps that did not use any type of bait. In Nueva Pompeya (Chaco), Uranotaenia was reported to be the most abundant genus captured with CDC light traps (Ramírez PG 2008). In the present study, no specimens of this species or Culex (Microculex) species were captured on the presented hosts, despite the significant percentages of larvae that have been found in nearby larval habitats (Stein et al. 2011).

Lourenço-de-Oliveira et al. (1986) also found recorded high percentages of mosquito larvae, but did not observe adults of the same species on any type of bait (which included humans, horses, cows, cats, sheep and frogs) (Lourenço-de-Oliveira \& Heyden 1986). They classified these species as haematophagous on poikilothermic animals, such as amphibians and reptilians.

Our results do not allow us to confirm the existence of changes in host selection patterns among different environments. Only $C x$. bidens and $C x$. maxi showed significant habitat-associated host selection, as they were more attracted to chickens in the urban habitat, but preferred rabbits in the semi-urban and wild habitats. Our data did not allow us to explain this finding.

With respect to temporal activity, our findings showed similarities to studies conducted in Argentina, Brazil and Venezuela (Hack et al. 1978, Lourenço-de-Oliveira et al. 1985, Mendez et al. 2001). Ochlerotatus, Psorophora, Wyeomyia and Haemagogus species are predominantly diurnal, while Anopheles, Culex, Mansonia and Coquillettidia species are crepuscular and nocturnal (Forattini 1965 a, b, Hack et al. 1978, Lourenço-de-Oliveira et al. 1985, Brochero et al. 2006). In Colombia, Murillo et al. (1988) also captured Anopheles species at sunrise. Hack 
et al. (1978) referred to Ps. ciliata as showing diurnal and nocturnal periodicity and Ps. confinnis and Ps. varinervis as presenting a nocturnal periodicity.

Some species recorded in the present study are involved in the transmission of diseases to humans or have been found to be naturally infected with different arboviruses (Gabaldon et al. 1977, Calisher et al. 1981, 1985, Natal 1981, Mitchell et al. 1985). Oc. albifasciatus is often found to be naturally infected with the Western equine encephalitis (WEE) virus. This species presents a wide distribution in Argentina and shows a preference for mammals, particularly horses and cattle. In addition, laboratory studies have found that it is a competent vector for the WEE virus (Avilés et al. 1992, Sabattini et al. 1998).

Many Culex species are vectors of arboviruses in South America. Cx. quinquefasciatus is a vector of the SLEV in Argentina. Many other arboviruses have been isolated from Cx. quinquefasciatus, including Oropouche virus in Brazil. Vertical transmission of the Japanese encephalitis virus has also been demonstrated in this species (Lourenço-de-Oliveira \& da Silva 1985, Johansen et al. 2001, Almirón et al. 2005). Calisher et al. (1985) and Mitchell et al. (1985) isolated three different viruses the Pará, WEE and Rio Negro [Venezuelan equine encephalitis (VEEV), subtype VI] viruses\} from $C x$. ocossa mosquitoes captured in Antequeras and near the Negro River in Chaco. The epidemic and enzootic cycles of virus transmission involving mosquitoes belonging to the Melanoconion subgenus also involve rodents and birds (Calisher et al. 1985, Mitchell et al. 1985).

Ma. titillans, Oc. scapularis and Ps. ferox have been found to be naturally infected with the VEEV virus, Rocio virus and UNA virus, respectively (Forattini et al. 1978, 1987, 1995, 1997, Travassos da Rosa et al. 1998, Mendez et al. 2001). In the USA, WNV was isolated from $C x$. pipiens and Ps. ferox after the first major outbreak recorded in birds, horses and people (CDC 2000). The Eastern equine encephalitis and VEEV viruses have been isolated from Oc. fulvus in Colombia (Delgado et al. 2005). Both An. triannulatus and An. albitarsis play a secondary role in malaria transmission in South America when they are present at high densities (Curto et al. 2003, Póvoa et al. 2006, Zimmerman et al. 2006).

Several authors have observed that the species found in the present study show a wide host selection range. It is also noteworthy that a high percentage of species were common to both the animal and human bait, indicating that these mosquito species could transmit arboviruses to humans in this region. The identified species also revealed certain patterns of host selection, different degrees of anthropophilia or zoophilia and, within the latter, different degrees of feeding preferences for birds or mammals. An increased versatility of a species' feeding pattern increases its potential to serve as a vector to spread a zoonotic pathogen (Tempelis et al. 1967). Similarly, as several species were detected throughout the year and throughout the day, these behavioural patterns contribute to their contacting different hosts and affect a mosquito's vector status. Knowledge of the issues outlined here could be useful for developing control strategies for diseases transmitted by mosquitoes in this region.

\section{REFERENCES}

Almirón WR, Brewer M 1995. Preferencia de hospedadores de Culicidae (Diptera) recolectados en el centro de la Argentina. Rev Saude Publica 29: 108-114.

Almirón WR, Brewer ME 1996. Winter biology of Culex pipiens quinquefasciatus Say, (Diptera: Culicidae) from Córdoba, Argentina. Mem Inst Oswaldo Cruz 91: 649-654.

Almirón WR, Diaz A, Spinsanti L, Ré V, Visintín A, Farías A, Contigiani M 2005. Importancia sanitária de los mosquitos. Brote de encefalitis de San Luis en Córdoba en 2005. Jornada de Actualización en Enfermedades de Transmisión Vectorial/VIII Simposio Internacional sobre Control Epidemiológico de Vectores, Fundación Mundo Sano, Buenos Aires, p. 3.

Avilés G, Sabattini MS, Mitchell CJ 1992. Transmission of western equine encephalomyelitis virus by Aedes albifasciatus (Diptera: Culicidae). J Med Entomol 29: 850-853.

Berti J, Guzmán H, Liria J, González J, Estrada Y, Pérez E 2011. Nuevos registros de mosquitos (Diptera: Culicidae) para el estado de Bolívar, Venezuela. Dos de ellos nuevos para el país. Bol Malariol Salud Ambient 51: 59-69.

Beskow GG, Spinsanti LI, Stein M, Gorodner JO, Contigiani MS 2007. Seroprevalencia de flavivirus y alfavirus en humanos en el NEA. Resultados preliminares. Revista de la Facultad de Medicina de la Universidad Nacional del Nordeste 25: 41.

Bidlingmayer WL 1985. The measurement of adult mosquito populations - some considerations. J Am Mosq Control Assoc 1: 328-347.

Bram RA 1967. Classification of Culex subgenus Culex in the new world (Diptera: Culicidae). Proc US Nat Mus 120: 1-122.

Brochero H, Pareja PX, Ortiz G, Olano VA 2006. Sitios de cría y actividad de picadura de especies de Anopheles en el municipio de Cimitarra, Santander, Colombia. Biomédica 26: 269-277.

Burkett-Cadena ND, Graham SP, Hassan HK, Guyer C, Eubanks MD, Katholi CR, Unnasch TR 2008. Blood feeding patterns of potential arbovirus vectors of the genus Culex targeting ectothermic hosts. Am J Trop Med Hyg 79: 809-815.

Calisher CH, Laziuck JS, Justines G, Francy DB, Monayh TP, Gutierrez E, Sabattini MS, Bowen GS, Jacob WL 1981. Viruses isolated from Aedeomyia squamipennis mosquitoes collected in Panama, Ecuador and Argentina: establishment of the gamboa serogroup. Am J Trop Med Hyg 30: 219-223.

Calisher CH, Monath TP, Mitchell JC, Sabattini MS, Cropp CB, Kerschner J, Hunt AR, Lazuick JZ 1985. Arbovirus investigations in Argentina. III. Identification and characterization of viruses isolated, including new subtypes of Western and Venezuelan Equine Encephalitis viruses and four new Bunyaviruses (Las Maloyas, Resistencia, Barranqueras and Antequera) Am J Trop Med Hyg 34: 956-965.

CDC - Centers for Disease Control and Prevention 2000. West Nile virus activity - Eastern United States, 2000. MMWR 49: 1044-1047.

Charlwood JD 1979. Estudos sobre a biologia e hábitos alimentares de Culex quinquefasciatus Say de Manaus, Amazonas, Brasil. Acta Amaz 9: 271-278.

Consoli RAGB, Lourenço-de-Oliveira R 1994. Principais mosquitos de importância sanitária no Brasil, Editora Fiocruz, Rio de Janeiro, $228 \mathrm{pp}$.

Curto SI, Carbajo AE, Boffi R 2003. Aplicación de sistemas de información geográfica en epidemiología. Caso de estudio: malaria en la Argentina (1902-2000). Available from: epidemiologia.anm. edu.ar/pdf/publicaciones_cie/2003/Aplicacion_Sistemas_Informacion_Geografica_epidemiologia_2003.pdf. 
da Silva MAN, Lozovei AL 1998. Mosquitos capturados com isca humana em área preservada de Curitiba, Paraná. Rev Bras Zool 15: 965-976.

Darsie RF 1985. Mosquitoes of Argentina. Part I. Keys for identification of adult females and fourth stages larvae in English and Spanish (Diptera: Culicidae). J Am Mosq Control Assoc 17: 153-253.

Delgado FAM, Zorro JAC, Jimenez LCV 2005. Las encefalitis equinas en salud pública. Available from: col.ops-oms.org/prevencion/encefalitis/libro_encefalitis.pdf.

Di Rienzo JA, Casanoves F, Balzarini MG, Gonzalez L, Tablada M, Robledo CW 2011. InfoStat versión 2011. Available from: infostat.com.ar.

Diaz LA, Komar N, Visitin A, Dantur Juri MJ, Stein M, Lobo Allende R, Spinsanti L, Konigheim B, Aguilar J, Laurito M, Almirón WR, Contigiani M 2008. West Nile virus in birds, Argentina. Emerg Infect Dis 14: 689-691.

Dye C 1992. The analisys of parasite transmission by blood-sucking insect. Annu Rev Entomol 37: 1-19.

Edman JD, Downe ER 1964. Host - Blood sources and multiple feeding habits of mosquitoes in Kansas. Mosq News 24: 154-160.

Forattini OP 1962. Entomologia médica. Parte geral, Diptera, Anophelini, Vol. I, Universidade de São Paulo, São Paulo, 622 pp.

Forattini OP 1965a. Entomologia médica. Culicini: Culex, Aedes, Psorophora, Vol. II, Universidade de São Paulo, São Paulo, 506 pp.

Forattini OP 1965b. Entomologia médica. Culicini: Haemagogus, Mansonia, Culiseta. Sabethini. Toxorhynchitini. Arboviruses. Filariose bancroftiana. Genetica, Vol. III, Universidade de São Paulo, São Paulo, 416 pp.

Forattini OP, Castro Gomes A, Natal D, Kakitani I 1987. Frequência domiciliar e endofilia de mosquitos Culicidae no Vale do Ribeira, São Paulo, Brasil. Rev Saude Publica 21: 188-192.

Forattini OP, Gomes AC, Galato EAB, Robillo EX, Iversson LB 1978. Estudos ecológicos sobre mosquitos Culicidae no Sistema da Serra do Mar, Brasil. 2. Observaciones no ambiente domiciliar. Rev Saude Publica 12: 476-496.

Forattini OP, Kakitani I, Massad E, Marucci D 1995. Studies on mosquitoes (Diptera: Culicidae) and anthropic enviroment. 9. Synanthropy and epidemiological vector role of Aedes scapularis in south-eastern Brazil. Rev Saude Publica 29: 199-207.

Forattini OP, Kakitani I, Mureb Sallum MA 1997. Encontro de criadouros de Aedes scapularis (Diptera: Culicidae) em recipientes artificiais. Rev Saude Publica 31: 519-522.

Gabaldon A, Ulloa G, Pulido J, Sutil E 1977. Especies de la familia Culicidae que presentan ornitofilia en Venezuela. Bol Dir Malariol y San Amb 17: 25-43.

Garcia-Rejon J, Bradley EJ, Blitvich J, Farfan-Ale A, Loroño-Pino MA, Chi Chim WA, Flores-Flores LF, Rosado-Paredes E, BaakBaak C, Perez-Mutul J, Suarez-Solis V, Fernandez-Salas I, Beaty BJ 2010. Host feeding preference of the mosquito Culex quinquefasciatus in Yucatan state, Mexico. J Insect Sci 10: 1-12.

Gomes A de C, Foratini OP, Natal D 1987. Composição e actividade de mosquitos Culicidae. Emprego de armadilha CDC no Vale do Ribeira, estado de São Paulo, Brasil. Rev Saude Publica 33: 95-97.

Hack WH, Torales GJ, Bar ME, Oscherov B 1978. Observaciones etológicas sobre culícidos de Corrientes. Rev Soc Entomol Argent 37: 137-151.

Johansen CA, Van den Hurk AF, Pyke AT, Zborowski P, Phillps DA, Mackenzie JS, Ritchie SA 2001. Entomological investigations of an outbreak of Japanese encephalitis virus in the Torres Strait, Australia, in 1998. J Med Entomol 38: 581-588.
Kilpatrick AM, Kramer LD, Jones MJ, Marra PP, Daszak P 2006. West Nile virus epidemics in North America are driven by shifts in mosquito feeding behavior. PLoS Biol 4: 82 .

Klein TA, Lima JBP, Tang AT 1992. Seasonal distribution and diel biting patterns of culicine mosquitoes in Costa Marques, Rondônia, Brazil. Mem Inst Oswaldo Cruz 87: 141-148.

Lane J 1953. Neotropical Culicidae, Vol. I and II, Universidade de São Paulo, São Paulo, 1112 pp.

Lefèvre T, Gouagna L-C, Dabiré KR, Elguero E, Fontenille D, Renaud F, Costantini C, Thomas F 2009. Beyond nature and nurture: phenotypic plasticity in blood-feeding behavior of Anopheles gambiae s.s. When humans are not readily accessible. Am J Trop Med Hyg 81: 1023-1029.

Lourenço-de-Oliveira R 1984. Alguns aspectos da ecologia dos mosquitos (Diptera: Culicidae) de uma área de planície (Granjas Calábria), em Jacarepaguá, Rio de Janeiro. I. Frequência comparativa das espécies em diferentes ambientes e métodos de coleta. Mem Inst Oswaldo Cruz 79: 479-490.

Lourenço-de-Oliveira R, da Silva TF 1985. Alguns aspectos da ecologia dos mosquitos (Diptera: Culicidae) de uma área de planície (Granjas Calábria), em Jacarepaguá, Rio de Janeiro. III. Preferência horária das fêmeas para o hematofagismo. Mem Inst Oswaldo Cruz 80: 195-201.

Lourenço-de-Oliveira R, da Silva TF, Heyden R 1985. Alguns aspectos da ecologia dos mosquitos (Diptera: Culicidae) de uma área de planície (Granjas Calábria), em Jacarepaguá, Rio de Janeiro. II. Frequência mensal e no ciclo lunar. Mem Inst Oswaldo Cruz 80: 123-133.

Lourenço-de-Oliveira R, Heyden R 1986. Alguns aspectos da ecologia dos mosquitos (Diptera: Culicidae) de uma área de plainície (Granjas Calábria), em Jacarepaguá, Rio de Janeiro. IV. Preferências alimentares quanto ao hospedeiro e frequência domiciliar. Mem Inst Oswaldo Cruz 81: 15-27.

Lourenço-de-Oliveira R, Heyden R, da Silva TF 1986. Alguns aspectos da ecologia dos mosquitos (Diptera: Culicidae) de uma área de planície (Granjas Calábria), em Jacarepaguá, Rio de Janeiro. V. Criadouros. Mem Inst Oswaldo Cruz 81: 265-271.

Lourenço-de-Oliveira R, Luz SLB 1996. Simian malaria at two sites in the Brazilian Amazon - II. Vertical distribution and frequency of anopheline species inside and outside the forest. Mem Inst Oswaldo Cruz 91: 687-694.

Mendez W, Liria J, Navarro JC, García CZ, Freier JE, Salas R, Weavwe SC, Barrera R 2001. Spatial dispersión of adult mosquitoes (Diptera: Culicidae) in a sylvatic focus of Venezuelan equine encephalitis virus. J Med Entomol 38: 813-821.

Mitchell JC, Monath TP, Sabattini MS, Cropp C, Daffner J, Calisher C, Christensen H 1985. Arbovirus investigations in Argentina. II. Arthropod collections and virus isolations from mosquitoes, 1977-1980. Am J Trop Med Hyg 34: 945-955.

Mitchell JC, Monath TP, Sabattini MS, Daffner J, Cropp CB, Calisher CH, Darsie RF, Jakob WL 1987. Arbovirus isolations from mosquitoes collected during and after the 1982-1983 epizootic of western equine encephalitis in Argentina. Am J Trop Med Hyg 36: 107-113.

Murillo BC, Astaiza RV, Fajardo PO 1988. Biologia de Anopheles (Kerteszia) neivai H., D. \& K., 1913 (Diptera: Culicidae) en la Costa Pacífica de Colombia. III. Medidas de luminosidad y el comportamiento de picadura. Rev Saude Publica 22: 109-112.

Natal D 1981. Importancia epidemiológica de Culex subgénero Melanoconion (Diptera: Culicidae), MsD Thesis, Faculdade de Saúde Pública/Universidade de São Paulo, São Paulo, 89 pp.

Oria GI, Stein M, Gorodner JO 2002. Mosquitos, sus criaderos y factores socioculturales de la población en el nordeste argentino. 
Actualizaciones en artropodología sanitaria argentina, Serie Enfermedades Transmisibles, Publicación monográfica 2, Buenos Aires, p. 167-172.

Pisano MB, Stein M, Re VE, Farias A, Diaz LA, Sanchez Seco MP, Nuñes D, Santos C, Tenorio A, Almirón WR, Contigiani MS 2007. Circulación del virus de la encefalitis equina venezolana en la provincia de Chaco (Argentina). XXVII Reunión Científica Anual de SAV, Vaquerías, Córdoba. p. 40-41.

Póvoa MM, de Souza RTL, Lacerda RNL, Rosa ES, Galiza D, de Souza JR, Wirtz RA, Schlichting CD, Conn JE 2006. The importance of Anopheles albitarsis $\mathrm{E}$ and An. darlingi in human malaria transmission in Boa Vista, state of Roraima, Brazil. Mem Inst Oswaldo Cruz 101: 163-168.

Prosen AF, Martínez A, Carcavallo RU 1960. La familia Culicidae (Diptera) en la ribera fluvial de la provincia de Buenos Aires. An Inst Med Regional 2: 101-113.

Ramírez PG 2008. Composición y fluctuación temporal de mosquitos (Diptera: Culicidae) en Misión Nueva Pompeya, un área del impenetrable, provincia del Chaco, MsD Thesis, Universidad Nacional del Nordeste, Argentina, 19 pp.

Ronderos RA, Bachman AO 1962. A propósito del Complejo Mansonia (Diptera: Culicidae). Rev Soc Entomol Argent 25: 43-51..

Sabattini MS, Avilés G, Monath TO 1998. Historical, epidemiological and ecological aspects of arboviruses in Argentina: Flaviviridae, Bunyaviridae and Rhabdoviridae. In: APA Travassos da Rosa, PFC Vasconcelos, JFS Travassos da Rosa, An overview of arbovirology in Brazil and neighbouring countries, Intituto Evandro Chagas, Belém, p. 113-134.

Service MW 1993. Mosquito ecology: field sampling methods, 2nd ed., Elsevier Science Publishers, Essex, 988 pp.

Stein M, Ludueña-Almeida F, Willener JA, Almirón WR 2011. Classification of immature mosquito species according to character- istics of the larval habitat in the subtropical province of Chaco, Argentina. Mem Inst Oswaldo Cruz 106: 400-407.

Stein M, Oria GI, Almirón WR 2002. Principales criaderos para Aedes aegypti y culícidos asociados) en la provincia del Chaco, Argentina. Rev Saude Publica 36: 627-630.

Stein M, Oria GI, Almirón WE, Willener JA 2005. Fluctuación estacional de Aedes aegypti en Chaco, Argentina. Rev Saude Publica 39: $559-564$

Tempelis CH, Francy DB, Hayes RO, Lofy MF 1967. Variations in feeding patterns of seven culicine mosquitoes on vertebrate hosts in Weld and Larimer Counties Colorado. Am J Trop Med Hyg 16: 111-119.

Teodoro U, Guilherme ALF, Lozovei AL, Filo VLS, Sampaio AA, Spinosa RP, Ferreira MEMC, Barbosa OC, de Lima EM 1994. Mosquitos de ambientes peri e extradomiciliares na Região Sul do Brasil. Rev Saude Publica 37: 275-279.

Tissot AC, Navarro-Silva MA 2004. Preferência por hospedeiro e estratificaçao de Culicidae (Diptera) em área de remanescente florestal do parque Regional do Iguaçu, Curitiba, Paraná, Brasil. Rev Bras Zool 21: 877-886.

Travassos da Rosa JFS, Travassos da Rosa APA, Vasconcelos PFC, Pinheiro FP, Rodrigues SG, Travasos da Rosa ES, Dias LB, Cruz ACR 1998. Arboviruses isolated in the Evandro Chagas Institute, including some described for the first time in the Brazilian Amazon Region, their know hosts and their pathology for man. In AP Travassos da Rosa, PFC Vasconcelos, JFS Travassos da Rosa, An overview of arbovirology in Brazil and neighbouring countries, Instituto Evandro Chagas, Belém, p. 19-31.

Zimmerman RH, Galardo AK, Lounibos LP, Arruda M, Wirtz R 2006. Blood meal hosts of Anopheles species (Diptera: Culicidae) in a malaria-endemic area of the Brazilian Amazon. $J$ Med Entomol 43: 947-956. 
Absolute number of Culicidae females captured on chicken (C), rabbit (R) and human bait, in Resistencia (RS), Monte Alto (MA) and Kilometer 1031 (KM), in the province of Chaco, Argentina, from June 2001-May 2002

\begin{tabular}{|c|c|c|c|c|c|c|c|}
\hline \multirow[b]{2}{*}{ Species } & \multicolumn{6}{|c|}{ Females captured } & \multirow{2}{*}{$\begin{array}{c}\text { Human } \\
\text { bait }\end{array}$} \\
\hline & $\mathrm{C}$ & $\mathrm{R}$ & $\mathrm{C}$ & $\mathrm{R}$ & $\mathrm{C}$ & $\mathrm{R}$ & \\
\hline Aedeomyia squamipennis & 1 & - & 5 & - & 3 & - & - \\
\hline Anopheles albitarsis & 1 & - & - & - & - & - & $66^{b}$ \\
\hline Anopheles galvaoi & - & - & - & - & - & - & 4 \\
\hline Anopheles neomaculipalpus & - & - & - & - & - & - & 20 \\
\hline Anopheles triannulatus & - & - & 3 & 21 & 3 & 4 & $489^{b}$ \\
\hline Anopheles spp & - & - & 3 & 3 & 2 & - & 27 \\
\hline Cq. albicosta & - & - & 1 & - & - & - & 2 \\
\hline Coquillettidia nigricans & - & - & - & 3 & 1 & 1 & $21^{b}$ \\
\hline Coquillettidia shannoni & - & - & - & 1 & - & - & 1 \\
\hline Culex apicinus & 1 & - & - & 3 & - & 19 & - \\
\hline Culex bidens ${ }^{a}$ & 33 & 6 & 205 & 1,043 & 206 & 1,121 & 116 \\
\hline Culex chidesteri ${ }^{a}$ & 26 & 7 & 672 & 614 & 480 & 385 & 17 \\
\hline Culex clarki ${ }^{a}$ & - & - & 3 & 27 & 9 & 8 & 1 \\
\hline Culex coronator & 3 & - & 30 & 38 & 18 & 29 & - \\
\hline Culex delpontei & - & - & - & 5 & 1 & 1 & 6 \\
\hline Culex eduardoi & - & - & 3 & 5 & 24 & 18 & 1 \\
\hline Culex educator ${ }^{a}$ & - & - & 3 & 27 & 26 & 55 & 36 \\
\hline Culex hepperi & 1 & 1 & 1 & 5 & 2 & 0 & - \\
\hline Culex intrincatus ${ }^{a}$ & 1 & - & 7 & 19 & 19 & 66 & 18 \\
\hline Culex lahillei & - & 1 & 12 & 9 & 11 & 10 & 4 \\
\hline Culex maxi & 129 & 7 & 196 & 264 & 80 & 194 & 26 \\
\hline Culex mollis & - & - & - & 1 & 1 & & 1 \\
\hline Culex ocossa $a^{a}$ & - & - & - & 17 & 4 & 7 & 5 \\
\hline Culex quinquefasciatus ${ }^{a}$ & 1,984 & 316 & 1 & 4 & 4 & 1 & - \\
\hline Culex saltanensis & - & - & - & 1 & - & 6 & - \\
\hline Culex (Cux.) spp & 151 & 16 & 335 & 417 & 161 & 281 & 40 \\
\hline Culex (Mel.) spp & - & - & - & 9 & 4 & 9 & 3 \\
\hline Haemagogus spegazzini & - & - & - & - & - & - & 3 \\
\hline Mansonia flaveola & - & - & 1 & - & - & - & - \\
\hline Mansonia humeralis & - & - & 3 & 26 & - & 1 & 135 \\
\hline Mansonia indubitans & - & - & 9 & 12 & 1 & - & 19 \\
\hline Mansonia pseudotitillans & - & - & - & 1 & - & - & 5 \\
\hline Mansonia. titillans ${ }^{a}$ & - & - & 87 & 174 & 28 & 45 & $589^{b}$ \\
\hline Mansonia spp & - & - & 5 & 29 & 3 & 1 & 42 \\
\hline Ochlerotatus albifasciatus & - & - & - & - & - & 1 & 95 \\
\hline Ochlerotatus crinifer & - & - & - & - & - & 1 & - \\
\hline Ochlerotatus fulvus ${ }^{a}$ & - & - & - & 9 & 28 & 98 & 2 \\
\hline Ochlerotatus hastatus ${ }^{a}$ & - & - & 26 & 37 & 95 & 464 & 139 \\
\hline Ochlerotatus scapularis ${ }^{a}$ & - & - & 57 & 370 & 86 & 195 & $2,559^{b}$ \\
\hline Ochlerotatus serratus & - & - & 1 & - & - & 2 & 4 \\
\hline Ochlerotatus stigmaticus ${ }^{a}$ & - & - & 1 & 18 & 6 & 71 & 6 \\
\hline Ochlerotatus spp & - & - & 3 & 15 & 8 & 76 & 34 \\
\hline Psorophora albigenu ${ }^{a}$ & - & 1 & 2 & 18 & 2 & 7 & $279^{b}$ \\
\hline Psorophora albipes & - & - & - & - & - & - & 2 \\
\hline Psorophora ciliata ${ }^{a}$ & - & - & 2 & 8 & 1 & 20 & 56 \\
\hline Psorophora cingulata & - & - & - & 1 & - & 3 & 3 \\
\hline Psorophora confinnis & - & - & - & 4 & - & 7 & 22 \\
\hline
\end{tabular}




\begin{tabular}{|c|c|c|c|c|c|c|c|}
\hline \multirow[b]{2}{*}{ Species } & \multicolumn{6}{|c|}{ Females captured } & \multirow{2}{*}{$\begin{array}{c}\text { Human } \\
\text { bait }\end{array}$} \\
\hline & $\mathrm{C}$ & $\mathrm{R}$ & $\mathrm{C}$ & $\mathrm{R}$ & $\mathrm{C}$ & $\mathrm{R}$ & \\
\hline Psorophora cyanescens ${ }^{a}$ & 1 & 2 & 1 & 4 & 13 & 37 & 33 \\
\hline Psorophora discrucians ${ }^{a}$ & - & - & 1 & 15 & 6 & 22 & 3 \\
\hline Psorophora ferox ${ }^{a}$ & - & - & 33 & 69 & 83 & 702 & 322 \\
\hline Psorophora pallescens & - & - & - & 2 & - & 2 & - \\
\hline Psorophora varinervis & - & - & - & 1 & - & 3 & 24 \\
\hline Psorophora (Jan.) spp & - & - & 20 & 32 & 32 & 122 & 72 \\
\hline Uranotaenia nataliae & - & - & - & - & - & - & 1 \\
\hline Wyeomyia diabolica $^{a}$ & 1 & - & 3 & 64 & 21 & 283 & 5 \\
\hline Wyeomyia melanocephala & - & - & - & - & - & - & 7 \\
\hline Wyeomyia muelhensia & - & - & 1 & 24 & 4 & 69 & 8 \\
\hline Wyeomyia (Pho.) spp & - & - & 1 & 49 & 8 & 168 & 13 \\
\hline Total & 2,333 & 357 & 1,737 & 3,518 & 1,485 & 4,615 & 5,386 \\
\hline
\end{tabular}

$a$ : significant differences between females captured with chicken and rabbit bait; $b$ : significant differences between females captured with animal and human bait. 